\title{
INDICATION OF NATURAL BOREO-CONTINENTAL PINE SITES THROUGH DISCRIMINATION ANALYSIS OF THE SOIL BIOCHEMICAL AND WATER- HOLDING PROPERTIES
}

\author{
PAVEL SAMEC $\otimes^{1,2,}$, JIŘÍ VOLÁNEK ${ }^{1}$, ALEŠ BAJER ${ }^{1}$ \\ ${ }^{1}$ Departmemnt of Geology and Soil Science, Faculty of Forestry and Wood Technology, Mendel University, Zemědělská 3, 61300 Brno, Czech Republic; \\ e-mail:samec.p@czechglobe.cz \\ ${ }^{2}$ Global Change Research Institute of the Czech Academy of Sciences, Belidla 986/4a, 61300 Brno, Czech Republic
}

$\bowtie$ Corresponding author

Received: 11 March 2020 / Accepted: 19 May 2020

Abstract

Samec P., Volánek J., Bajer A.: Indication of natural boreo-continental pine sites through discrimination analysis of the soil biochemical and waterholding properties. Ekológia (Bratislava), Vol. 40, No. 1, p. 25-36, 2021

\begin{abstract}
Natural pine site differentiation is instrumental in the modification of Scots pine cultivation to environmental change. The aim of this study was to distinguish azonal pine sites in prevailing beechwood conditions by the means of soil property interrelationships. The study aimed at verifying assumptions (i) that intrinsic soil properties suggest differences at naturalness among various communities in the same mesoclimate, relief or on same soil group and (ii) whether pines differ from beechwoods uniformly or unevenly among different regional population areas. The verification was carried out by discrimination analysis of the $\mathrm{H}$ - and A-horizon forest soil properties at selected pine and beech stands in the Czech Republic between 2006 and 2015. Homogeneous pines were confirmed either on poorly developed or very infertile soils. Mixed pines were found on Cambisols. Complete separability was found between pines and beechwoods on Podzols due to inverse proportions of correlations among acid phosphomonoesterase (APMEA) and urease (UA) activities, $\mathrm{C}_{\text {org }}, \mathrm{C}_{\text {mic }}$, base saturation, bulk density and aeration. The inverse proportions among UA, $\mathrm{N}_{\text {tot, }} \mathrm{C}_{\mathrm{mic}}$ and soil hydrophysical properties conditioned the separability of pines on different soil groups than beechwoods. Soil indications of natural pines are related to phosphorus release by APMEA and site resistance to drought due to soil organic matter and water-holding capacity.
\end{abstract}

Key words: soil biochemical signatures, enzyme-organomineral complex, soil organic matter, soil desiccation, forest community.

\section{Introduction}

Scots pine (Pinus sylvestris L.) is an tolerant Euro-Siberian tree species found only on sites where other tree species cannot sustain themselves in the long term. The pine tolerance has made it possible to introduce it to the prevalent zonal site of mixed deciduous forest. Cultivation outside its natural sites has led to both greater growth and greater damage by environmental loads (Vacek et al., 2016). The recognition of natural pine sites allows adapting silvicultural practices of pine production to environmental change and helps avoiding the impact of loads. Although the differences between natural and unnatural sites are conditioned by permanent deviations in growth and stability of pine stands, natural pine sites are not uniformly different from zonal sites (Vacek et al., 2017). Uneven dissimilarity of pine sites is due to unsuitable soil fertility. Unsuited fertility is caused both by the co-occurrence of exposed relief and soil group and by the property variations of the soil environment (Sewerniak, Piernik, 2012). Different causes of unsuitable soil fertility break down the character of transitions between pine and zonal sites. Determining natural sites of individual tree species is indispensable both for the estimation of potential natural vegetation (PNV) and for the sustainable forest management differentiation.
The unequivocal localization of pine stand sustainable management depends both on PNV estimation method and on selection of indicative soil properties. PNV is estimated paleoecologically, geobotanically, geobiocoenologically or ecographically (Neuhäuslová et al., 1998). Palaeoecological methods differ from other approaches of ecological biogeography by fossil record evaluation. The evaluation includes analyses of pollen and fossil macro-residues of plants in sediments. Former vegetation classification is carried out by determination, dating and sedimentation environment reconstruction (Magri et al., 2006). Ecological biogeography methods assess the intersections of present vegetation and present environment. Unlike palaeoecological methods, they do not evaluate spatially and temporally isolated findings, but they determine the spatial context of vegetation and the environment by long-term observation of permanent occurrences of species in a closed interval of growth conditions. Geobotanic and geobiocoenological approaches both use relationship interpolations of natural plant communities and the environment to estimate the deviation between current state and PNV (Chiarucci et al., 2010). The difference between the geobotanical and geobiocoenological approaches is that the geobotanical classification depends on the persistent occurrence of indica-

(c) The Author(s) 2021. This is an open access article distributed under the terms of the CC BY-NC-ND license.

https://content.sciendo.com/view/journals/eko/eko-overview.xml 


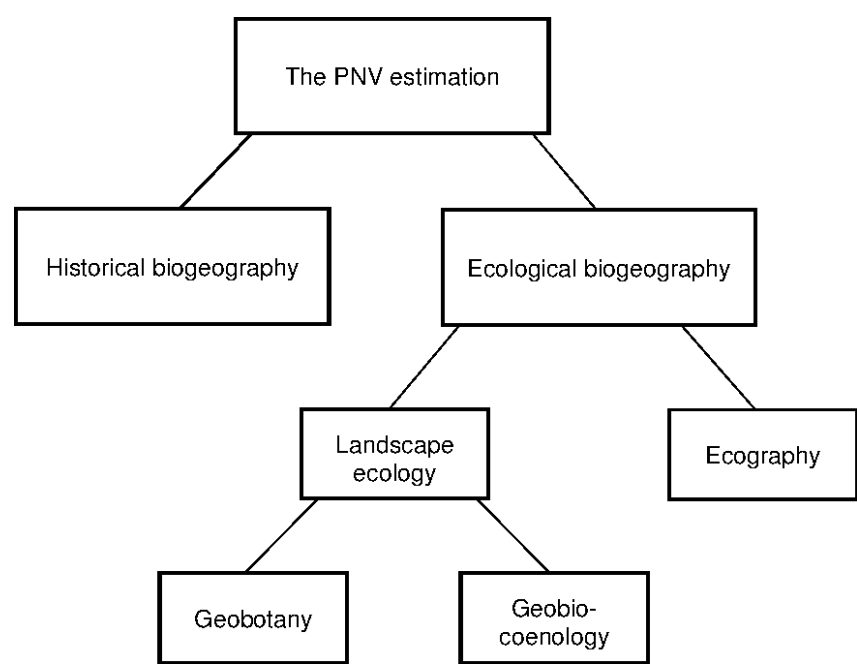

Fig. 1. Relations among methods of potential natural vegetation estimation.

tor species from natural communities under changed conditions, while the geobiocoenological classification estimates PNV from permanent environmental characteristics (Buček et al., 2015). The geobotanical classification estimates PNV before human influence, while geobiocoenological classification predicts a stable community after the end of human influences (Ostroumov, 2002). Ecographical approaches focus on processes that regulate environmental-plant relationships (Fig. 1), in which they detect properties similarly important for the development of PNV in unevenly distinct communities (MacLean, Wein, 1978).

Natural pines differ from zonal vegetation by their altitudinal climate independence. They occur in-between individual types of zonal plant communities in the marginal soil fertility conditions. Beechwoods predominate in the European mixed deciduous forest zone (Magri et al., 2006). Although pines occupy topographically similar reliefs of elevated areas as to ravine forests, they are more likely to occur at the edges of beechwoods than ravine communities (Šindelář et al., 2007). In flat relief pines often overgrow peat bogs along alder galleries rather than on transitions to waterlogged spruce forests (Sariyildiz, 2015). The occurrence of beechwoods in low altitudes is delimited by rainfall $<500 \mathrm{~mm}$, while below the upper tree limit is defined by average annual temperatures $<3.5^{\circ} \mathrm{C}$. Beechwoods are spread evenly on acidic or nutrient-rich soils within these marginal environmental site values, but do not permanently occur either on dry or waterlogged sites (Boublík, 2007). The natural dominance of beechwoods resides in feedback differentiation of root growth and soil organic matter decomposition between acidic and nutrient-rich sites. Conifers do not produce similar feedback, but they buffer adverse effects of acidic environment by slow humus decomposition (Elo et al., 2000).

The plant-soil feedback development depends upon the availability of nitrogen and phosphorus (Acea et al., 2003; Stevenson et al., 2004; Ponge, 2013). Sufficient amount of available nitrogen is an initial condition for mineral nutrient transport processes; biochemical weathering rate to decomposition intensity (Clarholm, Skyllberg, 2013). Plant activity is supplemented by organic acids release that contributes to soil acidification, but symbiosis with soil microorganisms suppresses it. Mycorrhizal fungi are more active in acidic environments, while rhizospheric bacteria in are active in nutrient-rich soils. Fungi buffer acidification by making mineral calcium and phosphorus accessible for plants, so that the occurrence of demanding species does not decrease (Blum et al., 2002). Rhizospheric bacteria promote root growth and access phosphorus from dead organic matter, but their effect on roots in acidic and nutrient-rich soils varies with calcium availability. Calcium not only speeds up organic polymer decomposition, but it differentiates the hormonal effect of organic acids on seed germination. The hormonal effect of organic acids from beech litter resembles auxins in acidic environment and gibberellins in neutral environment (Pizzeghello et al., 2001). The differentiation of biochemically made available nutrients, self-regulation of plant growth, including seed germination selection, stabilize the species composition of the community on acidic or nutrient sites leading to different ecosystem dynamics (Samec, 2008).

Soil biochemical properties indicate natural species composition of the ecosystem. The aim of this study is to distinguish natural pine sites from beechwoods with the use of soil property relationships. Intrinsic soil properties indicate site differences if various natural communities occur in similar mesoclimate, relief or on the same subsoil or soil group. Beechwoods possess advanced self-regulation soil biochemistry systems, while pines do not (Priha, Smolander, 1999). Autoregulation is indicated by the rate of biochemically controlled release of nutrients limiting for ecosystem functions. Biochemical nutrient release involves interactions between inorganic compounds, dead organic matter and soil organisms through enzymatic activity (Rao et al., 2000; Roscoe et al., 2000; Weintraub et al., 2007). Extracellular enzymatic activity is stabilized and perpetuated through enzyme-soil particle associations: resistant enzymeorganomineral complexes (EOMCs), which condition the rate of nutrient release. The formation of EOMCs is proportional to the supply of organic matter and bedrock type (Datta et al., 2017). Biochemical nutrient release is independent of the plant community disturbance by the virtue of EOMCs, but is related to permanent growth conditions formed by mineral composition of the soil or the stability of soil dead organic matter (Lehmann, Kleber, 2015). Natural pines and beechwoods differentiation is based on distinguishing the relationship tightness of enzymatic activity and soil environment. While beechwoods are unique in complex plant and soil relationships, the accumulation of humus on weathered subsoil in pines also creates a unique environment of relationships between soil, enzymes and organic matter (Ponge, 2016). The tightness of these relationships between enzymes and the soil environment indicates both the naturalness of the plant community and the adaptability to environmental change.

\section{Material and methods}

A comparison of naturally prevailing European temperate beechwoods with natural pine sites consisted of extensive forest soil sampling and selection of indicative soil properties (Samec, 2006). The comparison focused on the relationships among soil property characteristics and the differentiability of forest ecosystem types. 


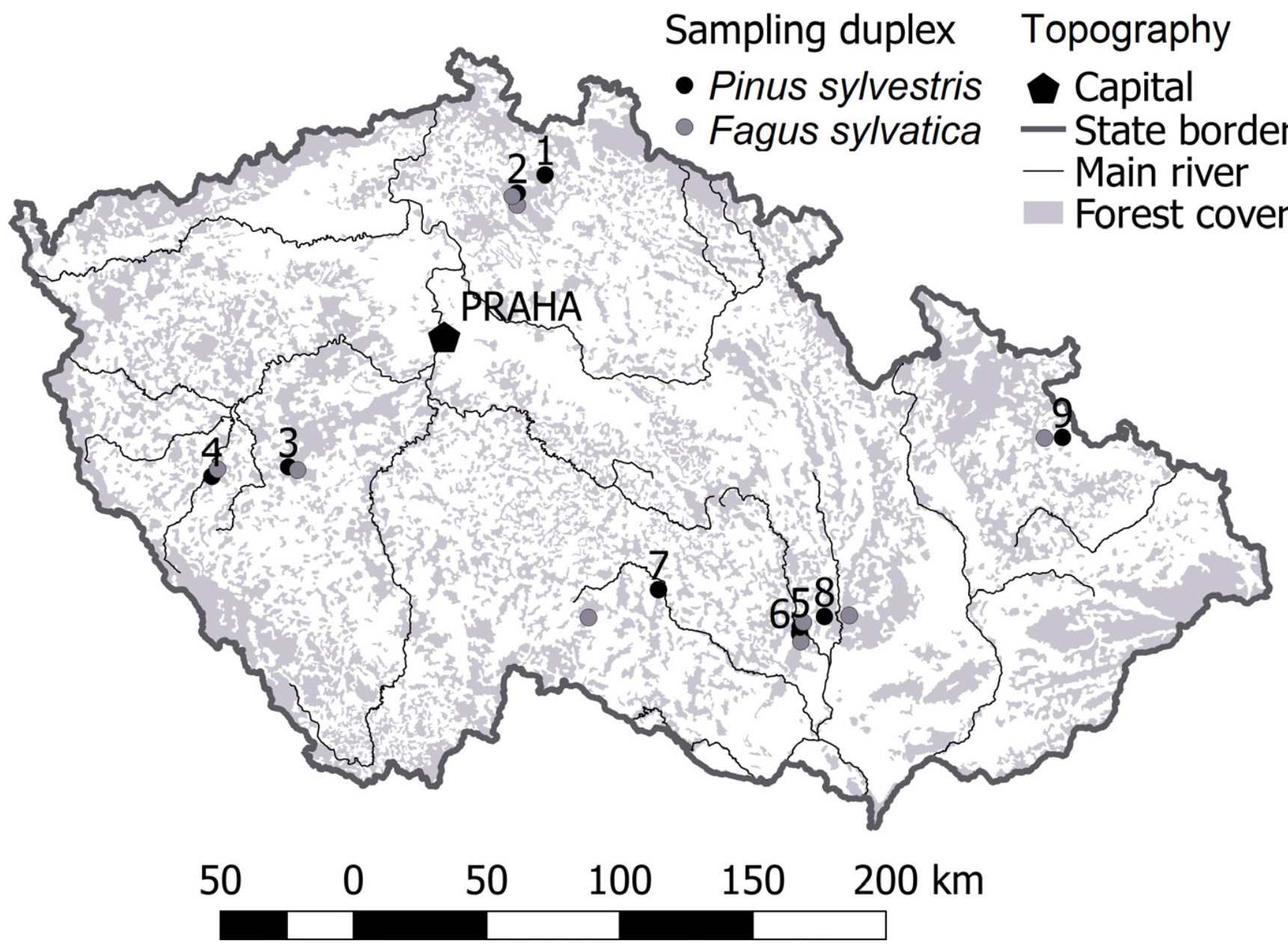

Fig. 2. Distribution of sampled stands with Scots pine (Pinus sylvestris) and European beech (Fagus sylvatica) in the Czech Republic (for detail information see Table 1).

\section{Investigated ecosystems}

The compared forest soils were selected in areas of regional Hercynian boreo-continental pine populations in the Czech Republic (Vacek et al., 2017). Hercynian biogeographical sub-province covers $66,810 \mathrm{~km}^{2}$ of the Czech Republic (84.73\%). The current forested area of the Hercynian sub-province is $35.45 \%$. Natural proportion of Scots pine (Pinus sylvestris) in the Hercynian subprovince is $4 \%$, while current occurrence is commercially extended to $17.8 \%$ (Culek, 2013). Natural beechwoods represented by European beech (Fagus sylvatica L.) that historically covered $72.3 \%$ of the sub-province are now reduced to $6.4 \%$ (Kučera, 2016).

Hercynian pines are bog or dry. Bog pines account for almost $16 \%$ and dry pines account for the remaining $84 \%$. Dry pines are not a monotone set of communities, but cover considerably different sites characterized by either undeveloped alkaline and acidic soils or developed infertile soils. Dry pines are classified according to soil acidity into serpentine (1.4\%), forest-steppe $(0.1 \%)$ and boreo-continental $(82.5 \%)$. The serpentine pines populate alkaline serpentinites, forest-steppe pines occur on marlstones and calcareous sandstones characterized by alternate waterlogging and desiccation, while boreo-continental pines oc- cupy rocky areas (cf. Neuhäuslová et al., 1998; Chytrý et al., 2010; Mikeska et al., 2008).

Ecosystem selection focused on natural communities. Boreo-continental pines were selected in forest areas where they prevail or are endemic. Prevalent pines were sampled in northern and western Bohemia, while endemic ecotypes were sampled in the Bohemian-Moravian Highlands and in the Low Jeseník Mts (Šindelár et al., 2007). The populations were sampled at two sites except for the Jeseník population, which does not occur on azonal sites. Each sampled locality had a counterpart beechwood site of predominant relief and soil group in the area (Fig. 2; Table 1). Selected ecosystems were characterized by morphometric features of relief, altitude, slope and exposure, parent rock, soil group and humus form (Derome et al., 2007). The pine and beech populations of the same forest area were characterized as a cluster of sampled soils. Sampling of surface humus (H-) and A-horizons was performed in two years during the vegetation season (May-September) in the period of 2006-2015.

\section{Soil properties}

Soil property analyses focused on desiccation indication, fertility and release of limiting nutrients. Hydrophysical, physico- 


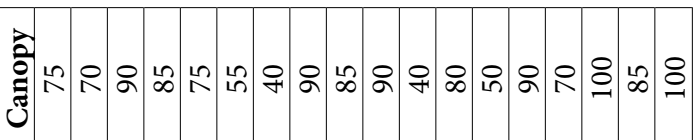

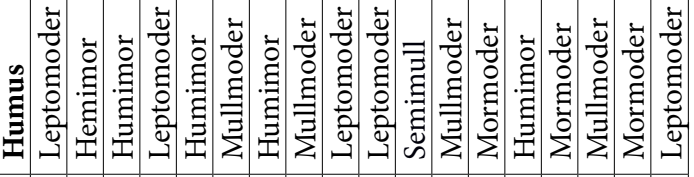

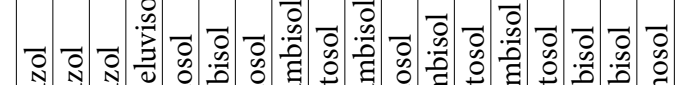

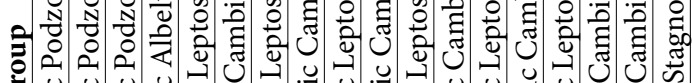

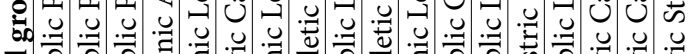

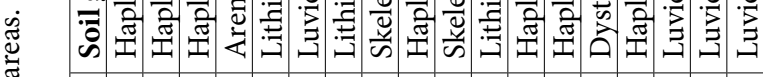

要

胥

苂

๑ั

के

辛

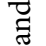

(⿻)

के

苍

:

के

艹

$\exists$

莡

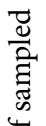

प्ञ

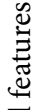

.

苛

ญ़

㐫

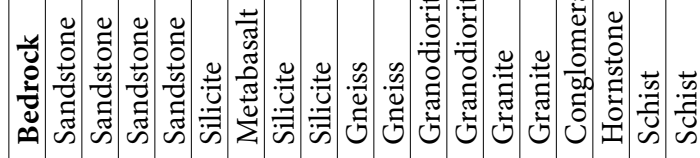

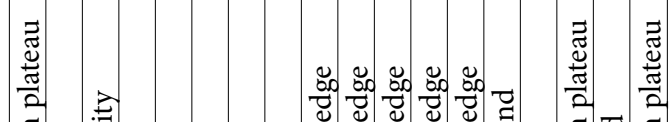

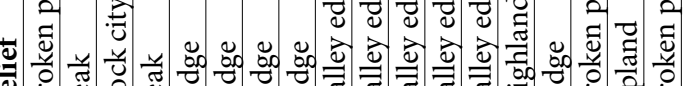
幽

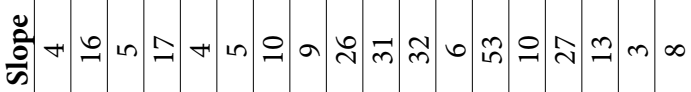

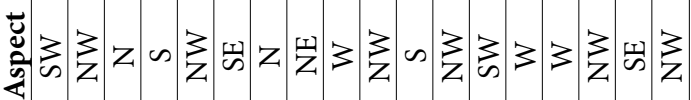

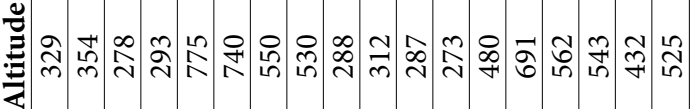

$\%$ \%

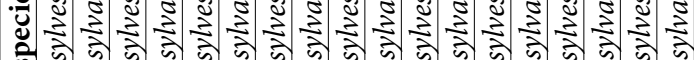

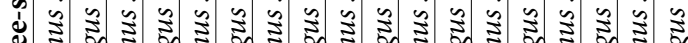

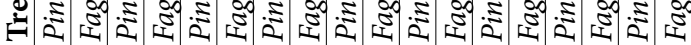

\section{离}

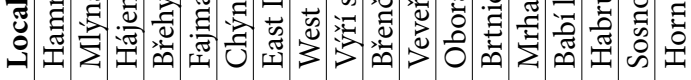

\begin{tabular}{|c|c|c|c|c|c|c|c|c|}
\hline$\stackrel{\Xi}{\Xi}$ & - & $\sim$ & $n$ & + & in & 6 & $\wedge$ & $\infty$ \\
\hline
\end{tabular}

\begin{tabular}{|c|c|c|c|c|c|}
\hline 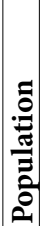 & 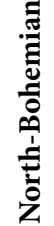 & 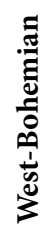 & 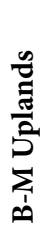 & 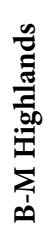 & 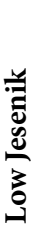 \\
\hline
\end{tabular}

ஸૈ: ๑

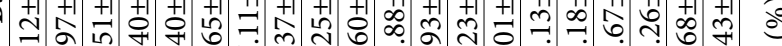
خ்

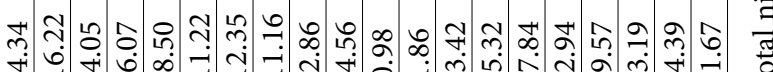

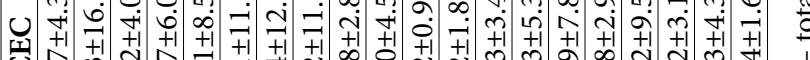

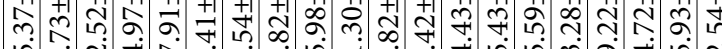

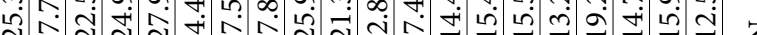

○)

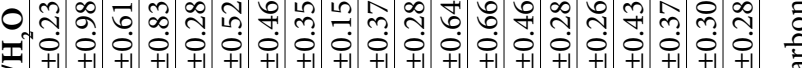

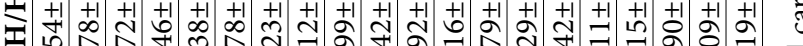
일

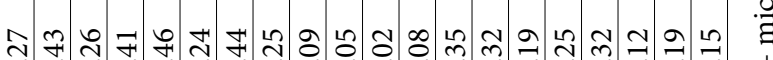

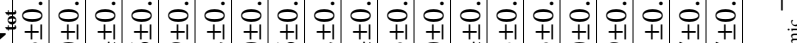

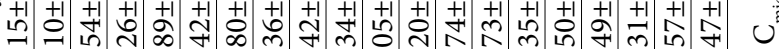

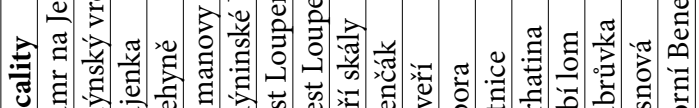

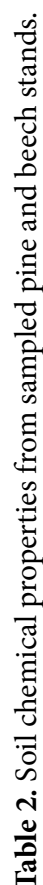

นุํำ

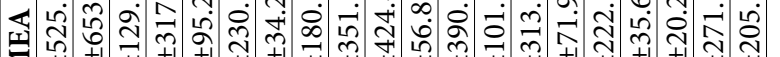

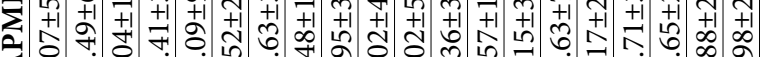

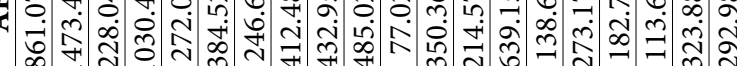

రิ)

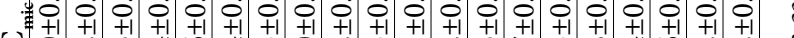

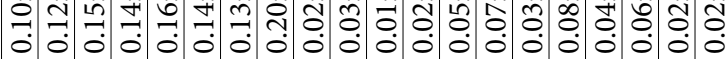

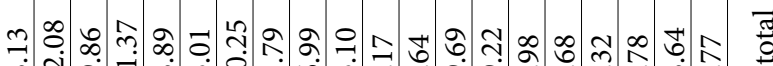

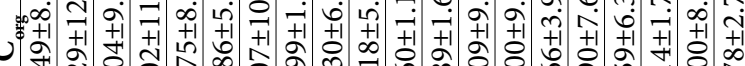
(n)

苾

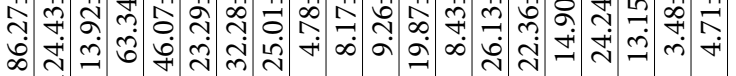
$\underset{\Xi}{\Xi}$

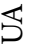
ठิ $\dot{0}$ क्ष

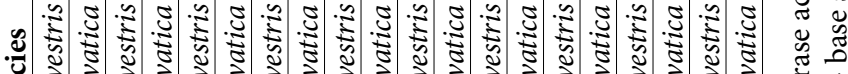

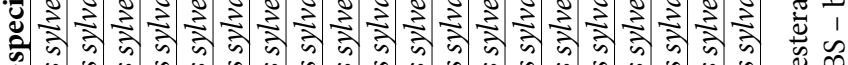

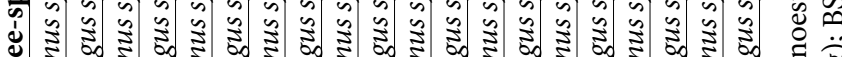
न हो

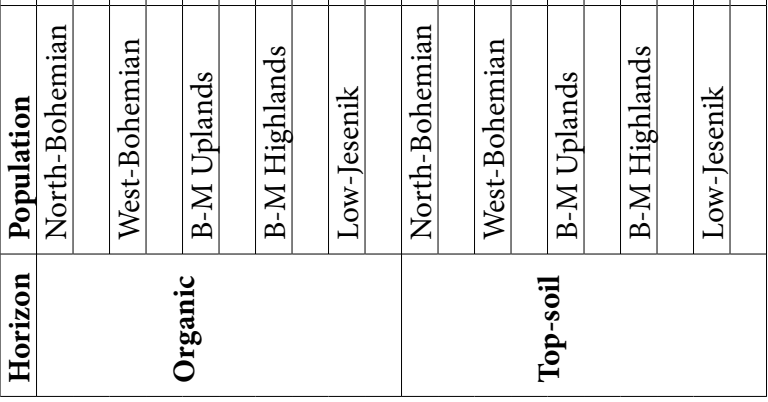

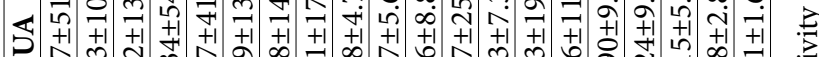


chemical and biochemical properties of interest point to interactions between inorganic compounds, dead organic matter and microbial communities in ecosystem self-regulatory processes (Cohran et al., 1989). Soil groups were characterized with the use of the WRB-ISSS-ISRIC classification (Michéli et al., 2007). Surface humus was classified according to Green et al. (1993). Soil desiccation was assessed using hydrophysical properties: bulk $\left(D_{\mathrm{d}}\right)$ and specific $\left(D_{\mathrm{s}}\right)$ densities, water-holding capacity (WHC), porosity (P) and aeration (A) (Samec et al., 2014). Fertility was assessed by $\mathrm{pH}$, sorption complex and $\mathrm{C} / \mathrm{N}$ in accordance with soil buffering evaluation (Ulrich, 1995). Soil $\mathrm{pH}$ was determined acidometrically. Soil sorption complex was characterized by cation exchange capacity (CEC) and base saturation (BS). CEC was found as the sum of the exchange cation concentrations by extraction in $0.1 \mathrm{M} \mathrm{BaCl}_{2}$ and $\mathrm{BS}$ as the proportion of the exchange bases from the CEC (Vanmechelen et al., 1997). Soil carbon $\left(\mathrm{C}_{\text {org }}\right)$ and nitrogen $\left(\mathrm{N}_{\text {tot }}\right)$ were detected spectrophotometrically by instrumental mineralization (Buckee, 1994).

Assessment of nutrient release was based on the determination of soil microbial biomass and enzymatic activity (Priha et al., 1999; Roscoe et al., 2000; Elfstrand et al., 2007). Microbial biomass was estimated from microbial carbon $\left(\mathrm{C}_{\text {mic }}\right)$ by oxidation-titration. $\mathrm{C}_{\text {mic }}$ was calculated as the difference in extractable carbon compound contents between fumigated $\left(\mathrm{C}_{\mathrm{f}}\right)$ and nonfumigated $\left(\mathrm{C}_{\text {org }}\right)$ samples $\left(\mathrm{C}_{\text {mic }}=\mathrm{C}_{\mathrm{f}}-\mathrm{C}_{\text {org }}\right)$ (Brookes et al., 1985). Biochemical activity assessment consisted of soil urease and phosphatase determinations. Biochemical activity was established from the difference between basal and substrate-induced samples by comparative incubation at optimal $\mathrm{pH}$ and $37^{\circ} \mathrm{C}$. Urease activity (UA) was derived from the decomposition of $0.08 \mathrm{M}$ $\mathrm{CO}\left(\mathrm{NH}_{2}\right)_{2}$ at $\mathrm{pH} 9.65$ in borate buffer (Kandeler, Gerber, 1988). Acid phosphomonoesterase activity (APMEA) was derived from the decomposition of $p$-nitrophenyl phosphate ( $p$-NPP $\check{s} p$-NP + $\mathrm{PO}_{4}^{3-}$ ) in succinate-borate buffer at $\mathrm{pH} 4.8$ (Rejšek, 1991).

Enzymes are unique in high specificity of catalysed biological reactions. $\mathrm{C}_{\text {mic }}$ suggests the amount of organic matter bound in microbial communities, which reduces the amount of nutrients available to plants (Weintraub et al., 2007). While UA indicates the release of nitrogen from the breakdown of protein residues, APMEA indicates the release of phosphorus from organic matter. Parallel releases of nitrogen and phosphorus are key processes of making macrobiogenic substance, essential to plant growth, available (Cohran et al., 1989). Available nitrogen released by UA is deduced from the total amount of generated ammonium nitrogen $\left(\mathrm{N}-\mathrm{NH}_{4}^{+}\right)$. Phosphatase released accessible phosphorus is

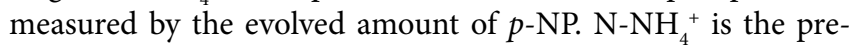
dominant form of accessible nitrogen and orthophosphoric acid esters from dead organic matter are generally the only source of accessible phosphorus for plants (Hyvönen et al., 2000; Rejšek, 2006; Kang et al., 2010).

\section{Statistical analysis}

\section{Inner-soil relationships}

Statistical analysis of inner-soil environment focused on assessment of biochemical properties and enzyme-organomineral complex relationships using linear correlations at $p<0.05$. Soil properties were divided into $\mathrm{H}$ - and A-horizons in pine and beech stands. Correlations were evaluated between (bio)chemical properties of soil organic matter with soil physical chemistry and hydrophysics. Significant correlations of soil carbon or nitrogen content indicated the effect of organic matter on soil physicochemical or hydrophysical properties (Ponge, 2013). Significant correlations of enzymatic activity indicated the effect of EOMCs on the nutrient release stabilization (Rao et al., 2000).

\section{Ecosystem discrimination}

The differences in EOMCs between azonal and zonal forest ecosystems were assessed using linear discrimination analysis (LDA). LDA use prerequisites have been verified using normality and covariance tests. Normality was evaluated from an absolute skewness value of $<1$ (Webster, 2001). Populations of pine ecotypes were compared with beechwoods in the same forest areas. The differences between pines and beechwoods have been described by separability and discriminatory function (Park et al., 2006).

\section{Results}

\section{Site differences}

Compared pine and beech stands were of similar altitude ranges, smallest inclinations and exposures, same meso-relief and parent rock. The pines were sampled at altitudes of 278-775 m. The west Bohemian pine forests were of the highest altitude, the north Bohemian pine forests of the lowest. The inclination of pine sites ranged $3-53^{\circ}$ and northern, northwestern to western rocky slopes with outcrops of mostly acidic sediments prevailed. The beechwoods were sampled at altitudes of 273-740 m most on northwestern rocky slopes with $5-31^{\circ}$ inclination and with balanced outcrop frequency of sediments and igneous rock. Bohemian-Moravian upland stands were sampled at the lowest altitudes, while western Bohemian to Bohemian-Moravian highland stands were sampled at the highest altitudes. Most of the Bohemian-Moravian upland stands were located $<300 \mathrm{~m}$ above sea level, while upland stands were sampled at altitudes of $>550$ $\mathrm{m}$ a.s.l. Pines most commonly grew on Leptosols with Mormoders or Humimors, while beechwoods covered Cambisols with Mulloders and Leptomoders (Table 1).

\section{Soil properties}

Soil properties of the compared ecosystems were significantly differentiated depending on soil horizons, tree species, region and altitude. Compared soil properties, except for $\mathrm{pH}$, reached higher values in the $\mathrm{H}$-horizons than in the A-horizons. Higher $\mathrm{H}$-horizon $\mathrm{pH}$ was associated with beech stands only, while in pines it was higher only in the case of Czech-Moravian Highlands. The differences in soil horizon characteristics between the ecosystems compared depended not only on the tree species but also on the location of the community. Beech stands were characteristic by higher APMEA and base saturation in H-horizons irrespective of the region of occurrence, while A-horizons always showed higher $\mathrm{C}_{\text {mic }}$ values (Table 2). The values of urease activity, $\mathrm{C}_{\text {org }}, \mathrm{N}_{\text {tot }}$, CEC, $\mathrm{pH}$ and hydrophysical properties were rather altitude or region of occurrence dependent. Higher UA, $\mathrm{C}_{\text {org }}$, 
Table 3. Top soil hydrophysical properties from sampled pine and beech stands.

\begin{tabular}{|l|l|c|c|c|c|c|}
\hline Population & Tree-species & $\boldsymbol{D}_{\boldsymbol{d}}$ & $\boldsymbol{D}_{\boldsymbol{s}}$ & WHC & P & A \\
\hline \multirow{2}{*}{ North-Bohemian } & Pinus sylvestris & $1.38 \pm 0.10$ & $2.53 \pm 0.15$ & $19.55 \pm 5.39$ & $45.56 \pm 3.95$ & $35.56 \pm 5.19$ \\
\cline { 2 - 7 } & Fagus sylvatica & $1.06 \pm 0.24$ & $2.43 \pm 0.19$ & $35.67 \pm 9.36$ & $56.63 \pm 7.61$ & $28.96 \pm 9.58$ \\
\hline \multirow{2}{*}{ West-Bohemian } & Pinus sylvestris & $0.39 \pm 0.13$ & $1.70 \pm 0.18$ & $58.66 \pm 6.87$ & $77.1 \pm 6.71$ & $61.52 \pm 8.55$ \\
\cline { 2 - 7 } & Fagus sylvatica & $0.93 \pm 0.15$ & $2.40 \pm 0.14$ & $56.52 \pm 5.5$ & $61.38 \pm 5.08$ & $38.38 \pm 16.93$ \\
\hline \multirow{2}{*}{ B-M Highlands } & Pinus sylvestris & $0.91 \pm 0.28$ & $1.81 \pm 0.60$ & $25.83 \pm 9.36$ & $48.78 \pm 13.33$ & $42.53 \pm 14.16$ \\
\cline { 2 - 7 } & Fagus sylvatica & $1.20 \pm 0.05$ & $2.43 \pm 0.07$ & $36.31 \pm 4.39$ & $51.27 \pm 1.29$ & $35.84 \pm 3.64$ \\
\hline \multirow{2}{*}{ B-M Uplands } & Pinus sylvestris & $1.16 \pm 0.18$ & $2.30 \pm 0.24$ & $34.10 \pm 12.80$ & $51.35 \pm 9.69$ & $45.35 \pm 10.75$ \\
\cline { 2 - 7 } & Fagus sylvatica & $1.02 \pm 0.26$ & $2.38 \pm 0.23$ & $40.55 \pm 6.39$ & $57.80 \pm 7.95$ & $45.47 \pm 6.66$ \\
\hline \multirow{2}{*}{ Low-Jesenik } & Pinus sylvestris & $1.12 \pm 0.08$ & $2.40 \pm 0.07$ & $35.50 \pm 5.31$ & $53.16 \pm 3.43$ & $38.77 \pm 5.81$ \\
\cline { 2 - 7 } & Fagus sylvatica & $1.14 \pm 0.13$ & $2.46 \pm 0.05$ & $46.91 \pm 3.42$ & $53.87 \pm 4.47$ & $21.64 \pm 17.43$ \\
\hline
\end{tabular}

Notes: $D_{\mathrm{d}}$ - bulk density $\left(\mathrm{g} / \mathrm{cm}^{3}\right) ; D_{\mathrm{s}}$ - specific density $\left(\mathrm{g} / \mathrm{cm}^{3}\right)$; WHC - water-holding capacity (\%); P - porosity (\%); A - aeration (\%).

Table 4. Soil property skewness of sampled pine and beech stands (for description of the properties see Table 2).

\begin{tabular}{|c|c|c|c|c|c|c|c|c|c|c|}
\hline Horizon & Population & Tree-species & APME & UA & $\mathrm{C}_{\text {org }}$ & $\mathrm{C}_{\text {mic }}$ & $\mathbf{N}_{\text {tot }}$ & $\mathrm{pH}$ & CEC & BS \\
\hline \multirow{12}{*}{ Organic } & \multirow{2}{*}{ North-Bohemian } & Pinus sylvestris & -0.45 & -0.73 & 9.49 & -1.16 & 5.94 & -0.71 & 8.46 & 8.91 \\
\hline & & Fagus sylvatica & 0.14 & 0.24 & -0.17 & 0.10 & -0.20 & 0.58 & 2.70 & -1.21 \\
\hline & \multirow{2}{*}{ West-Bohemian } & Pinus sylvestris & 0.06 & 1.54 & -1.06 & 0.47 & -1.19 & 1.13 & -0.27 & 0.88 \\
\hline & & Fagus sylvatica & 0.38 & 0.62 & -0.16 & 1.40 & -0.32 & 0.33 & 1.51 & -0.48 \\
\hline & \multirow{2}{*}{ B-M Uplands } & Pinus sylvestris & 0.28 & 1.33 & 0.58 & -0.11 & 0.46 & -0.09 & -1.36 & -1.12 \\
\hline & & Fagus sylvatica & 1.04 & 0.22 & 0.52 & -0.36 & 0.29 & 0.07 & 2.23 & 0.35 \\
\hline & \multirow{2}{*}{ B-M Highlands } & Pinus sylvestris & 0.79 & 1.17 & -0.10 & -1.11 & 0.19 & 0.16 & -0.23 & -0.39 \\
\hline & & Fagus sylvatica & -0.05 & 1.23 & -0.89 & 0.37 & 0.85 & -0.30 & 0.62 & 1.14 \\
\hline & \multirow{2}{*}{ Low-Jesenik } & Pinus sylvestris & 0.37 & 1.10 & -0.34 & 0.01 & 0.13 & -0.24 & 1.72 & 0.11 \\
\hline & & Fagus sylvatica & 0.97 & 0.97 & 0.36 & -0.37 & 1.55 & 0.95 & 2.16 & 0.03 \\
\hline & \multirow{2}{*}{ Total } & Pinus sylvestris & 2.57 & 1.54 & -0.42 & 0.32 & 5.42 & 0.16 & -0.12 & 1.28 \\
\hline & & Fagus sylvatica & 1.15 & 1.98 & -0.46 & -0.13 & -0.63 & 0.82 & 2.14 & -0.33 \\
\hline \multirow{12}{*}{ Top-soil } & \multirow{2}{*}{ North-Bohemian } & Pinus sylvestris & -1.53 & 0.01 & 8.16 & 1.15 & 9.26 & -0.87 & 5.72 & -0.28 \\
\hline & & Fagus sylvatica & 2.09 & 1.20 & 0.76 & 0.24 & -0.51 & 1.12 & 0.04 & 0.98 \\
\hline & \multirow{2}{*}{ West-Bohemian } & Pinus sylvestris & 0.65 & 0.76 & 0.35 & 1.16 & 0.78 & 0.55 & 0.04 & 1.79 \\
\hline & & Fagus sylvatica & 0.57 & 0.63 & 0.58 & 0.70 & 0.63 & -0.50 & -0.21 & 0.97 \\
\hline & \multirow{2}{*}{ B-M Uplands } & Pinus sylvestris & 2.72 & 0.94 & 0.66 & 0.30 & 0.74 & 0.12 & 0.14 & -1.20 \\
\hline & & Fagus sylvatica & 1.51 & 0.64 & 0.71 & 0.34 & 0.43 & 1.49 & 0.92 & 0.41 \\
\hline & \multirow{2}{*}{ B-M Highlands } & Pinus sylvestris & 0.85 & 1.08 & 2.46 & 0.57 & 0.81 & -0.45 & 2.51 & -1.07 \\
\hline & & Fagus sylvatica & 0.67 & 0.52 & 0.63 & 1.22 & 0.09 & 0.60 & 0.62 & 0.08 \\
\hline & \multirow{2}{*}{ Low-Jesenik } & Pinus sylvestris & 0.96 & 0.88 & 0.55 & 0.78 & 0.04 & -0.53 & -0.15 & -0.15 \\
\hline & & Fagus sylvatica & 1.03 & 0.76 & 1.14 & -0.04 & 1.41 & 1.33 & 0.84 & 1.98 \\
\hline & \multirow{2}{*}{ Total } & Pinus sylvestris & 2.40 & 0.84 & 1.16 & 0.83 & 6.20 & -0.36 & 1.07 & 1.56 \\
\hline & & Fagus sylvatica & 1.60 & 1.62 & 1.73 & 1.35 & 1.24 & 0.52 & 0.34 & 1.48 \\
\hline
\end{tabular}

and $\mathrm{N}_{\text {tot }}$ values in beech $\mathrm{H}$-horizons were regionally determined, while beech A-horizons were characteristic in some regions apart from UA also by higher $\mathrm{pH}, \mathrm{CEC}, D_{\mathrm{s}}$, WHC, porosity and aeration than pine soils (Table 3 ). Altitude increase not only indicated linear dependence of higher values of soil properties in beech stands, but also a symmetrical distribution in middle altitudes of North Bohemian, Jeseník and Bohemian-Moravian highland stands. Higher $\mathrm{C}_{\text {mic }}, \mathrm{pH}$ and $\mathrm{CEC}$ values in beech humus were distributed symmetrically along an altitudinal gradient. While the higher $\mathrm{C}_{\text {mic }}$ values were characteristic for the mid-altitude beech forests, the physico-chemical properties of humus were lower either in the Bohemian-Moravian Highlands, or in Low Jeseník, respectively. APMEA, $\mathrm{C}_{\text {org }}, \mathrm{N}_{\text {tot }}$, BS and $D_{\mathrm{d}}$ influenced higher value dependence of beech A-horizons on altitude, but only base saturation appeared symmetrically divided with lower values in the Bohemian-Moravian Highlands and in the Low Jeseník Mts. In contrast, higher APMEA, $\mathrm{C}_{\text {org }}, \mathrm{N}_{\text {tot }}$, and $D_{\mathrm{d}}$ appear to be linearly dependent on altitude in beech A-horizons.

Differences in the skewness of the value distribution were conditioned not only by the tightness differences of linear cor- 
Table 5. Linear correlation (bold at $p<0.05)$ of soil biochemical properties with hydrophysical and physicochemical properties.

\begin{tabular}{|c|c|c|c|c|c|c|c|c|}
\hline Horizon & Tree-species & Quality & AKFE & AU & $\mathrm{C}_{\mathrm{org}}$ & $\mathrm{C}_{\text {mic }}$ & $\mathbf{N}_{t}$ & $\mathrm{C} / \mathrm{N}$ \\
\hline \multirow{6}{*}{ Organic } & \multirow{3}{*}{ Pinus sylvestris } & $\mathrm{pH}$ & -0.35 & 0.19 & -0.75 & 0.32 & -0.51 & -0.14 \\
\hline & & CEC & 0.02 & -0.11 & 0.20 & 0.35 & 0.31 & -0.12 \\
\hline & & BS & -0.08 & -0.46 & 0.11 & 0.01 & 0.37 & -0.28 \\
\hline & \multirow{3}{*}{ Fagus sylvatica } & $\mathrm{pH}$ & 0.12 & 0.08 & -0.61 & 0.24 & -0.54 & -0.31 \\
\hline & & CEC & -0.18 & 0.05 & 0.09 & 0.24 & 0.06 & 0.07 \\
\hline & & BS & 0.41 & 0.02 & -0.30 & -0.15 & -0.24 & -0.25 \\
\hline \multirow{16}{*}{ Top-soil } & \multirow{8}{*}{ Pinus sylvestris } & $\mathrm{pH}$ & -0.11 & 0.51 & -0.38 & 0.02 & -0.21 & -0.33 \\
\hline & & CEC & 0.34 & 0.12 & 0.58 & 0.41 & 0.66 & -0.31 \\
\hline & & BS & 0.10 & -0.31 & -0.04 & 0.02 & 0.13 & -0.38 \\
\hline & & $D_{\mathrm{d}}$ & -0.32 & 0.07 & -0.61 & -0.56 & -0.70 & 0.22 \\
\hline & & $D_{\mathrm{s}}$ & -0.23 & 0.00 & -0.52 & -0.37 & -0.67 & 0.29 \\
\hline & & WHC & 0.36 & -0.19 & 0.45 & 0.34 & 0.46 & -0.19 \\
\hline & & $\mathrm{P}$ & 0.25 & -0.15 & 0.48 & 0.49 & 0.48 & -0.08 \\
\hline & & $\mathrm{A}$ & 0.12 & 0.06 & 0.33 & 0.50 & 0.39 & -0.14 \\
\hline & \multirow{8}{*}{ Fagus sylvatica } & $\mathrm{pH}$ & 0.19 & 0.36 & -0.19 & -0.05 & -0.05 & -0.51 \\
\hline & & $\mathrm{CEC}$ & -0.07 & 0.10 & 0.51 & 0.36 & 0.61 & -0.27 \\
\hline & & BS & -0.02 & -0.23 & -0.04 & -0.09 & -0.01 & -0.04 \\
\hline & & $D_{\mathrm{d}}$ & -0.13 & -0.07 & -0.55 & -0.05 & -0.42 & -0.37 \\
\hline & & $D_{\mathrm{s}}$ & 0.18 & 0.25 & -0.35 & -0.06 & -0.29 & -0.22 \\
\hline & & WHC & 0.51 & 0.50 & 0.40 & -0.13 & 0.47 & -0.21 \\
\hline & & $\mathrm{P}$ & 0.17 & 0.16 & 0.55 & 0.04 & 0.40 & 0.40 \\
\hline & & $\mathrm{A}$ & 0.03 & 0.45 & 0.32 & 0.35 & 0.18 & 0.22 \\
\hline
\end{tabular}

relations, but also by the separability of soil properties between $\mathrm{H}$ - and A-horizons. The normality of $\mathrm{pH}$ distribution occurred simultaneously in both soil horizons of all ecosystem populations studied. The distribution of other soil properties did not correspond either between soil horizons or between compared ecosystems. In addition to $\mathrm{pH}$, carbon content normality was retained in the H-horizons of all ecosystems. On the other hand, the APMEA and UA distributions were skewed in both the pines and the beechwoods. However, APMEA was significantly skewed only in the hilly Czech-Moravian beech forests. Similarly, the humus $\mathrm{C}_{\text {org }}$ was sporadically skewed only in the North Bohemian pine stands. Slight skew of the hydrophysical properties occurred at all the compared A-horizons, $\mathrm{pH}$ normality alike. APMEA normality was violated in the assessment of all ecosystems, but unlike the $\mathrm{H}$-horizons, it was also violated among $\mathrm{C}_{\text {org }}, \mathrm{N}_{\text {tot }}$ and BS. The normality of all A-horizon biochemical and sorption property populations was not related to retaining the normality of the distribution of values in individual populations of pine or beech. It was not disrupted even occasionally among individual A-horizon populations, but $\mathrm{UA}, \mathrm{C}_{\text {mic }}, \mathrm{N}_{\text {tot }}$ and sorption properties were skewed in at least two different populations of the compared ecosystems (Table 4).

Soil organic matter influenced soil physical chemistry and hydrophysics differentially in various ecosystems and soil horizons. Pine organic matter affected soil $\mathrm{pH}$, bulk density and water-holding capacity more than beech matter. In contrast, the enzymatic activity of beech stands affected WHC more than in pines (Table 5). $\mathrm{C}_{\text {org }}$ and $\mathrm{N}_{\text {tot }}$ contents were higher at lower $\mathrm{pH}$, yet $\mathrm{C}_{\text {mic }}$ proportion decreased. $\mathrm{C}_{\text {mic }}$ was inversely proportional to the total organic carbon content, but did not correspond to higher $\mathrm{pH}$ or CEC. Total nitrogen content affected sorption of beech humus more than $\mathrm{C}_{\text {org }}$ content. Correlations of $\mathrm{C}_{\text {mic }}$ with A-horizons in beech stands were insignificant. $\mathrm{C} / \mathrm{N}$ ratio of beech humus did not affect $\mathrm{pH}$ or $\mathrm{CEC}$, but was inversely proportional to $\mathrm{BS}$. The inverse proportion between the pine humus $\mathrm{C} / \mathrm{N}$ and the physical chemistry of the A-horizons was statistically significant. Organic matter significantly influenced soil hydrophysical properties in both compared communities. Higher organic matter content further reduced bulk density and increased WHC. Porosity or aeration were increased more in beechwoods than in pines. $\mathrm{N}_{\text {tot }}$ in pines affected soil hydrophysical properties more than $\mathrm{C}_{\text {org }}$, but in beechwoods the influence of $\mathrm{C}_{\text {org }}$ was more pronounced.

Enzymatic activity influenced soil properties by more differentiated dependencies than organic matter content. Soil physicochemical properties were influenced specifically in different horizons under various communities. Both CEC and soil hydrophysical properties were not affected. APMEA was inversely proportional to $\mathrm{pH}$ in pine, but significantly increased BS only in beech humus. AU was inversely proportional to base saturation only in pine, but directly proportional to $\mathrm{pH}$ in both pine and beech A-horizons. Bulk density and porosity were only rarely affected. However, APMEA significantly increased WHC in both pines and beechwoods. AU increased water-holding capacity only in beechwoods.

\section{Ecosystem separability}

The soil environment separability of all populations of the compared pine and beechwood communities exceeded $50 \%$ in both monitored horizons. The separability of the A-horizons was on average higher than that of the $\mathrm{H}$-horizons due to the inclusion 


\begin{tabular}{|c|c|c|c|c|c|c|c|c|c|c|c|c|c|c|c|c|c|c|c|}
\hline$\varangle$ & & ' & I & & I & 1 & I & & ' & & \begin{tabular}{l}
$\frac{n}{7}$ \\
\hdashline \\
\hdashline
\end{tabular} & $\stackrel{m}{\stackrel{m}{\rightarrow}} \underset{+}{\infty}$ & : & 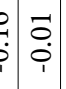 & $\exists$ & $\stackrel{n}{m}$ & $\begin{array}{l}\overrightarrow{0} \\
\dot{0} \\
1\end{array}$ & $\vec{m}$ & $\begin{array}{c}\mathfrak{n} \\
\\
i \\
\end{array}$ \\
\hline 岱 & & & ' & & 1 & ' & ' & ' & ' & & 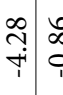 & \begin{tabular}{l|l}
0 & 0 \\
0 & 0 \\
0 & 7
\end{tabular} & 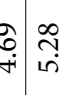 & 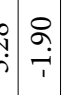 & 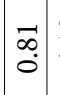 & $\begin{array}{c}0 \\
\vec{\varphi} \\
1\end{array}$ & $\stackrel{9}{\circ}$ & $\begin{array}{c}\widetilde{T} \\
-i \\
-1\end{array}$ & 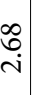 \\
\hline$a^{0}$ & & & ' & & ' & ' & ' & & ' & 1 & 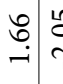 & 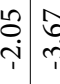 & 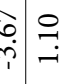 & 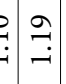 & $\mid \begin{array}{l}2 \\
\infty \\
0 \\
0\end{array}$ & $\vec{z}$ & $\begin{array}{l}\stackrel{\infty}{\stackrel{i}{i}} \\
\stackrel{1}{*}\end{array}$ & 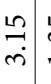 & $\stackrel{n}{\stackrel{n}{?}}$ \\
\hline$\tilde{\infty}$ & 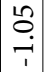 & $\begin{array}{c}\stackrel{ }{\mathcal{i}} \\
\vec{i}\end{array}$ & $\begin{array}{c}\infty \\
\substack{n \\
0}\end{array}$ & 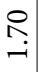 & $\begin{array}{l}\hat{0} \\
\dot{p} \\
i\end{array}$ & $\underset{\sim}{\stackrel{N}{-}}$ & $\underset{1}{\infty}$ & $\underset{+}{\stackrel{q}{+}}$ & $\mid \begin{array}{c}0 \\
i n \\
\text { in }\end{array}$ & 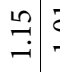 & ר: & $\vec{n}$ & 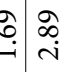 & $\begin{array}{lll}\hat{i} & \overrightarrow{\widehat{i}} \\
\dot{i}\end{array}$ & $\begin{array}{l}0 \\
0 \\
0 \\
1\end{array}$ & $\begin{array}{c}\underset{1}{\sim} \\
\text { i }\end{array}$ & $\begin{array}{l}0 \\
+ \\
\dot{1} \\
1\end{array}$ & $\begin{array}{l}\hat{\sigma} \\
\stackrel{\mathrm{j}}{ }\end{array}$ & 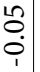 \\
\hline
\end{tabular}

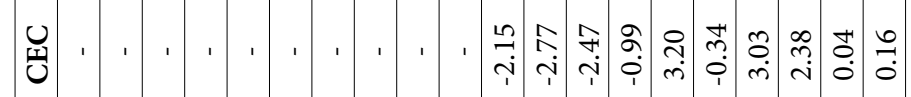

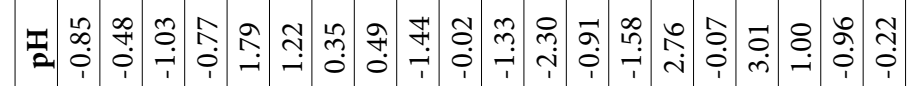

ํํํ

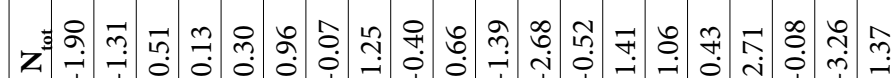

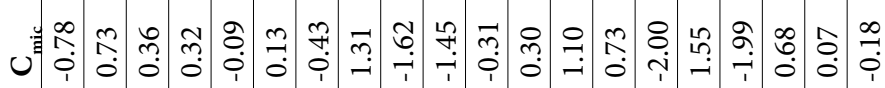

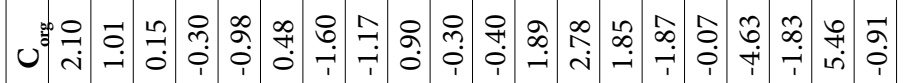

$\stackrel{\oplus}{\oplus}$

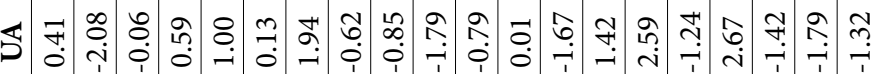

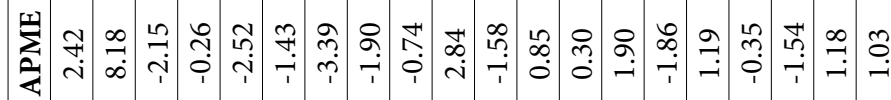

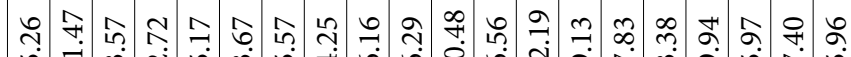

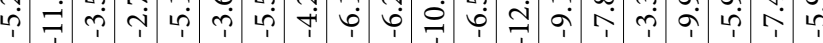

กิ

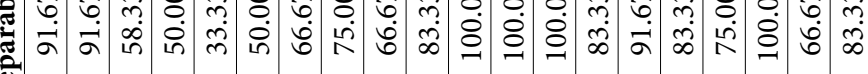

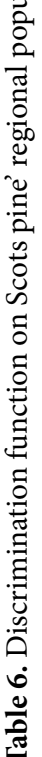
\&

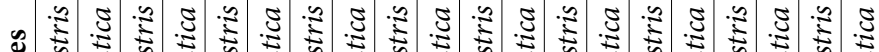

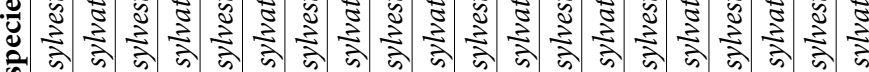

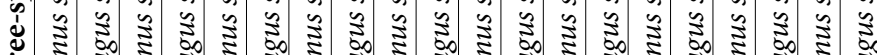

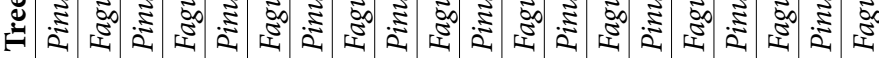

\begin{tabular}{|c|c|c|c|c|c|c|c|c|c|c|}
\hline 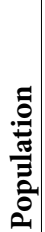 & 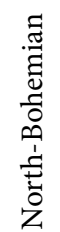 & 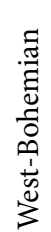 & 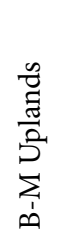 & 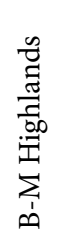 & 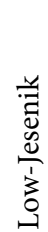 & 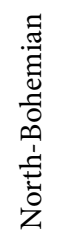 & 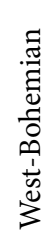 & 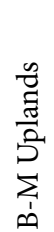 & 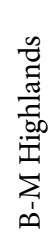 & 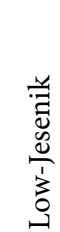 \\
\hline 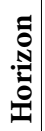 & & & 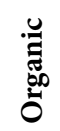 & & & & & $\begin{array}{l}7 \overline{0} \\
\dot{0} \\
\text { ô }\end{array}$ & & \\
\hline
\end{tabular}




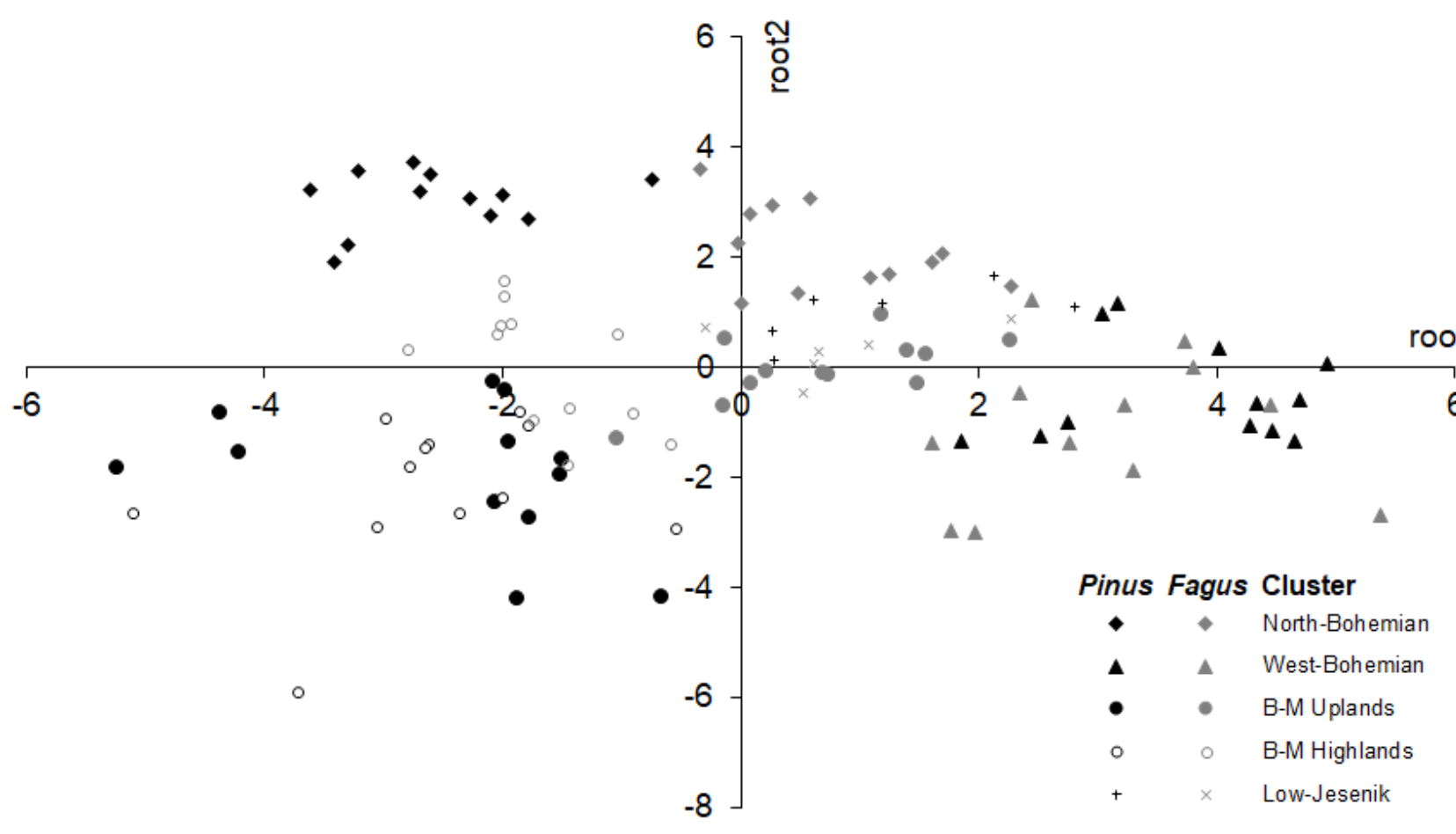

Fig. 3. Clusters from populations of sampled pine and beech forest soils.

of hydrophysical properties. While the average separability of H-horizons reached almost $66.7 \%$, the average separability of A-horizons exceeded $88.3 \%$. Soil characteristics were most different between North Bohemian pine and beech forests, despite differing the least in soil groups among the monitored stands. The differences between the North Bohemian forest ecosystems were greater than among the West Bohemian ecosystems, even with small variation of soil groups and small elevation difference of the compared communities. On the other hand, the lowest separability of $75 \%$ occurred between Jeseník mountain pine and beech forest on similarly developed soils.

Separability of North Bohemian pines to beechwoods was caused by inverse proportions of all chemical soil properties and inverse proportions among APMEA, UA, $\mathrm{C}_{\text {org }}, \mathrm{C}_{\text {mic }}, \mathrm{BS}, \mathrm{D}_{\mathrm{d}}$ and aeration. Separability of pine to beechwoods on different soil groups was determined by inverse proportions between UA, $\mathrm{N}_{\text {tot' }}$, $\mathrm{C}_{\text {mic }}$ and hydrophysical properties. The separability differences between populations of the compared communities were determined by alternating proportions between $\mathrm{pH}, \mathrm{CEC}, D_{\mathrm{d}}$ and aeration (Table 6). The altitude and linear combination of the roots of discriminatory functions influenced the probability of indication of natural occurrence of scots pine in individual regions. The separability differences between pine and beech forests on different soil groups in individual regions were altitude-dependent. The differences among the highest populations exceeded $16 \%$, while the lowest populations differed by less than $9 \%$. Lower altitude North Bohemian and Bohemian-Moravian upland pines were clearly separated from beechwoods by different proportions of canonical roots. On the contrary, higher altitude Bohemian-Moravian highland, West Bohemian and Jeseník pines were concentrated along similar values of canonical roots (Fig. 3). North-Bohemian, West-Bohemian and Bohemian-Moravian upland pines appear naturally homogeneous due to higher separability from beech forests while Jeseník or Bohemian-Moravian upland pines are mixed with European beech.

\section{Discussion}

The relationships among soil enzymatic activity, organic matter content and hydrophysics indicated natural azonal pine sites in prevailing beechwood conditions. The correlation of phosphatase activity with organic matter and water-holding capacity was more important than the occurrence of the azonal soil group to differentiate natural pines. Correlations of enzymatic activity with soil properties appear to be biochemical signatures of potential natural vegetation. PNV estimation through biochemical signatures is based on the derivation of the enzyme-organomineral complex influences the ecological stability of the plant community (Ponge, 2016). Achieving a stable plant community is not only the main intention of nature-friendly forest management, but it also strengthens the protection of forests against the impacts of harmful factors (Vacek et al., 2017). Soil biochemical signatures indicate the links among nature, ecological stability and sustainable forest use (Sariyildiz, 2015).

Soil enzyme-organomineral complexes are formed by enzyme to a clay mineral or organic matter adsorptions through physical interactions involving hydrogen bonds, ionic reactions and van der Waals forces (Fazekašová et al., 2013). The presence of enzyme-organomineral complexes was estimated from correlations of enzymatic activity with inversely proportional $\mathrm{C}_{\text {org }}$ and 
$\mathrm{C}_{\text {mic }}$ contents when comparing soil biochemistry of pines and beechwoods. The inverse proportion of $\mathrm{C}_{\text {org }}$ and $\mathrm{C}_{\text {mic }}$ in relation to enzymatic activity suggests different ratios between activities of intracellular and extracellular enzymes. Nevertheless, there is a strong linear relationship between intracellular and extracellular enzymes. Approximately $75 \%$ of acid phosphatase is found within living cells and only $25 \%$ is extracellular; however, exoenzymes are $60 \%$ more efficient (Tarafdar et al., 2001). The key producers of soil exoenzymes are microorganisms. Bacterial colonies follow soil carbon content; therefore intracellular enzymes are predominantly responsible for the biochemical activity of humus, while activity in A-horizons rests on extracellular enzymes (Hýsek, Šarapatka, 1998). The origin of the enzyme determines the degree of the catalytic effect preservation after adsorption. Catalytic effects change during adsorption due to structural deformations of the enzyme. Enzymes tend to increase the footprint of various conformational changes. The extent of enzyme deformation strictly depends on the structure of hard or soft proteins. Even so, adsorbed enzymes retain $90 \%$ of the catalytic activity on average (Datta et al., 2017). The differences between the production of intracellular and extracellular enzymes in upper soil horizons suggest why correlations between enzymatic activity and A-horizon properties were more separable than in humus. The strong dependence of enzymatic activity total on soil acidity and temperature meant that the separability of the compared forest ecosystems has varied between evaluated regions and altitudes (Kedi et al., 2013).

Soil biochemical signatures suggest PNV as a result of the stability and partial enzyme-organomineral complex independence on the composition of current vegetation. Soil particle adsorption protects enzymes from decomposition. At the same time, bound exoenzymes become independent of plant community species composition as opposed to intracellular enzymes, but their adsorption is directly dependent on organic matter decomposition (Nannipieri et al., 2003). Organic matter of pines influenced $\mathrm{pH}, \mathrm{D}_{\mathrm{d}}$ and WHC more than of beechwoods. Current composition of tree species affected humic APMEA and BS. On the other hand, urease activity, $\mathrm{C} / \mathrm{N}$, cation exchange capacity, $\mathrm{pH}$ and hydrophysical properties of A-horizons were more influenced by altitude. Altitudinal zonality confirms both the influence of external temperature conditions and the effect of differently weathering rocks on the functions of enzyme-organomineral complexes. The $\mathrm{pH}$ dependence of enzymatic activity indicates that the function of the enzyme complexes is dependent not only on soil organic matter activity but also on the parent material in the substratum. Therefore, the enzyme complexes correspond to the species composition of the forest before conversion and may indicate its original dominant woody species.

The relationships of the top soil horizon properties are more important for the PNV indication than the occurrence of the soil body group. While biochemical signatures have always distinguished pine trees from beechwoods, the incidence of soil group was different only in some regions. Altitude and parent rock condition the reliability discrepancy of pines indication. Soil group indicates whether natural pines are potentially homogeneous or mixed. Homogeneous natural pines populate poorly developed or eluviated soils with different enzymatic relationships with $\mathrm{C} / \mathrm{N}, \mathrm{C}_{\text {mic }}$, $\mathrm{BS}, D_{\mathrm{d}}$ and aeration. Mixed pines prevail on Cambisols (Vavríčcek, Chaloupka, 2005; Samec, 2006; Vacek et al., 2016). The occurrence of pines simultaneously on the same and different soil groups than beechwoods confirmed the assumption of uneven difference of pine sites (Vacek et al., 2017). Soil properties differed most between North Bohemian pines and beechwoods, which are mostly found on Podzols. The smallest differences between the soils of pines and beechwoods were found in the Jeseník Mts., where pine ecotype occurring together with deciduous trees on Cambisols was characterized (Šindelár et al., 2007). North Bohemian to West Bohemian and BohemianMoravian homogenous upland pine forests were confirmed on different soils than beechwoods. The Jeseník and isolated Bohemian-Moravian highlands mixed forests were distinguished on similar soils as beechwoods.

Direct dependence fluctuation between APMEA and WHC in different ecosystem types shows uneven resistance of pine stands. At the same time, soil WHC determines both drought resistance and the stability of nutrient availability of the ecosystem. Since APMEA values are conditioned by the humus content and the soil grain size, they are a feedback constituent between biocoenosis and soil body functions (Baveye, Wander, 2019). APMEA follows the availability of soil phosphorus, but the lack of water causes its random variations impacting all ecosystem functions. The activity of intracellular enzymes is higher than extracellular during wet periods due to the growth of microbial populations. In contrast, extracellular enzymes are more active during dry periods (Yavitt et al., 2004). Growth of microbial populations depletes available soil phosphorus, but sporulation after phosphorus depletion is accompanied by nutrient release from spilled cytoplasm. Released nutrients slow the decline of the microbial population (González-Pastor et al., 2003). Extracellular enzymes help to restore microbial populations in unfavourable times, thereby maintaining all related ecosystem functions. The dynamic equilibrium between microbial populations and soil organic matter decomposition maintained by extracellular phosphatases increases WHC and drought-resistance of forests.

\section{Conclusion}

Boreo-continental pines differ from beechwoods more significantly by correlations of soil biochemical and hydrophysical properties than by soil group occurrences. The differences in soil properties indicate whether the pines are naturally mixed or homogeneous under prevailing beechwood conditions. Correlations between acid phosphomonoesterase activity, organic matter content and water-holding capacity signified natural pine sites within prevailing beechwoods. Indication of natural pines is related to the dynamics of phosphorus release and soil desiccation. Homogeneous pine forests occur either on poorly developed or very infertile soils, while mixed pine forests, similarly to beech forests, are found on Cambisols. The distinction between pine and beech sites on the same soil bodies is related to distinct relationships between soil enzymes, $\mathrm{C} / \mathrm{N}, \mathrm{C}_{\text {mic }}$, base saturation, bulk density and aeration. Soil indication of pines implies not only an innovation of the potential natural vegetation characteristics, but also that the indication of azonal ecosystems are associated with the site resistance to desiccation.

\section{Acknowledgements}

The authors gratefully acknowledge the support by the Project LM2018123 CzeCOS of the Ministry of Education, Youth and Sports of the Czech Republic. 


\section{References}

Acea, M.J., Prieto-Fernández, A. \& Diz-Cid N. (2003). Cyanobacterial inoculation of heated soils: effects on microorganisms of $\mathrm{C}$ and $\mathrm{N}$ cycles on chemical composition in soil surface. Soil Biol. Biochem., 35, 513-524. DOI: 10.1016/S0038-0717(03)00005-1.

Baveye, P.C. \& Wander M. (2019). The (bio)chemistry of soil humus and humic substances: Why is the "new view" still considered novel after more than 80 years? Frontiers in Environmental Science, 7, 1-27. DOI 10.3389/fenvs.2019.00027.

Blum, J.D., Klaue, A., Nezat, C.A., Driscoll, C.T., Johnson, C.E., Siccama, T.G., Eagar, C., Fahey, T.J. \& Likens G.E. (2002). Mycorrhizal weathering of apatite as an important calcium source in base-poor forest ecosystems. Nature, 417, 729-731. DOI: 10.1038/nature00793.

Boublík, K. (2007). Pokus o rekonstrukci potenciálni přirozené vegetace vybraného území Třeboňské pánve. Zprávy České Botanické Společnosti, 42 155-170.

Brookes, P.C., Landman, A., Pruden, G. \& Jenkinson D.S. (1985). Chloroform fumigation and the release of soil nitrogen: a rapid direct extraction method to measure microbial biomass nitrogen in soil. Soil Biol. Biochem., 17, 837-842. DOI: 10.1016/0038-0717(85)90144-0.

Buckee, G.K. (1994). Determination of total nitrogen in barley, malt and beer by Kjeldahl procedures and the Dumas combustion method - Collaborative trial. J. Inst. Brew., 100, 57-64. DOI: 10.4236/ijg.2014.54042.

Buček, A., Habrová, H., Maděra, P., Král, K., Modrý, M., Lacina, J. \& Pavliš J. (2015). Application of Czech methodology of biogeographical landscape differentation in geobiocoenological concept - examples from Cuba, Tasmania and Yemen. Journal of Landscape Ecology, 8, 51-67. DOI: 10.1515/jlecol-2015-0014.

Chiarucci, A., Araújo, M., Decocq, G., Beierkuhnlein, C. \& Fernández-Palacios J. (2010). The concept of potential natural vegetation. J. Veg. Sci., 21, 1172-1178. DOI: 10.1111/j.1654-1103.2010.01218.x.

Chytrý, M., Kučera, T., Kočí, M., Grulich, V. \& Lustyk P. (Eds.) (2010). Katalog biotopů České republiky. Praha: Agentura ochrany prírody a krajiny ČR.

Clarholm, M. \& Skyllberg U. (2013). Translocation of metals by trees and fungi regulates $\mathrm{pH}$, soil organic matter turnover and nitrogen availability in acidic forest soils. Soil Biol. Biochem., 63, 142-153. DOI: 10.1016/j. soilbio.2013.03.019.

Cohran, V.L., Elliot, L.F. \& Lewis C.E. (1989). Soil microbial biomass and enzyme activity in subarctic agricultural and forest soils. Biol. Fertil. Soils 7, 283-288. DOI: 10.1007/BF00257821.

Culek, M. (2013). Biogeographical provinces, subprovinces and bioregions of the Czech Republic. Journal of Landscape Ecology, 6, 5-16. DOI: 10.2478/v10285-012-0065-5.

Datta, R., Anand, S., Moulick, A., Baraniya, D., Pathan, S.I., Rejšek, K. Vranová, V., Sharma, M., Keldar, A. \& Formánek P. (2017). How enzymes are adsorbed on soil solid phase and factors limiting its activity: A Review. International Agrophysics, 31, 287-302. DOI: 10.1515/ intag-2016-0049.

Derome, J., Lindgren, M., Merilä, P., Beuker, E. \& Nöjd P. (2007). Forest condition monitoring under the UN/ECE and EU programmes in Finland. Working Papers of the Finnish Forest Research Institute, 45, 11-20.

Elfstrand, S., Hedlund, K. \& Mårtensson A. (2007). Soil enzyme activities, microbial community composition and function after 47 years of continuous green manuring. Appl. Soil Ecol., 35, 610-621. DOI: 10.1016/j apsoil.2006.09.011.

Elo, S., Maunukcela, L., Salkinoja-Salonen, M., Smolander, A. \& Haahtela K. (2000). Humus bacteria of Norway spruce stands: plant growth promoting properties and birch, red fescue and alder colonizing capacity. FEMS Microbiol. Ecol., 31, 143-152.

Fazekašova, D., Boltižiar, M., Bobul'ska, L., Kotorova, D., Hecl, J. \& Krnáčová Z. (2013). Development of soil parameters and changing landscape structure in conditions of cold mountain climate (case study Liptovská Teplička). Ekológia (Bratislava), 32, 197-210. DOI: 10.2478/eko-20130017.

González-Pastor, J.E., Hobbs, E.C. \& Losick R. (2003). Cannibalism by sporulating bacteria. Science, 301, 510-513. DOI: 10.1126/science.1086462.

Green, R.N., Trowbridge, R.L. \& Klinka K. (1993). Towards a taxonomic classification of humus forms. For. Sci., 39, 1-49.
Hyvönen, R., Olsson, B.A., Lundkvist, H. \& Staaf H. (2000). Decomposition and nutrient release from Picea abies (L.) Karst. and Pinus sylvestris L. logging residues. For. Ecol. Manag., 126, 97-112. DOI: 10.1016/S03781127(99)00092-4.

Hýsek, J. \& Šarapatka B. (1998). Relationship between phosphatase active bacteria and phosphatase activities in forest soils. Biol. Fertil. Soils, 26, 112-115. DOI: $10.1007 / \mathrm{s} 003740050352$.

Kandeler, E. \& Gerber H. (1988). Short-term assay of soil urease activity using colorimetric determination of ammonium. Biol. Fertil. Soils, 6 , 68-72. DOI: 10.1007/BF00257924.

Kang, H., Xin, Z., Berg, B., Burgess, P.J., Liu, Q., Liu, Z., Li, Z. \& Liu C. (2010) Global pattern of leaf litter nitrogen and phosphorus in woody plants. Ann. For. Sci., 67, 811. DOI: 10.1051/forest/2010047.

Kedi, B., Abadie, J., Sei, J., Quiquampoix, H. \& Staunton S. (2013). Diversity of adsorption affinity and catalytic activity of fungal phosphatases adsorbed on some tropical soils. Soil Biol. Biochem., 56, 13-20. DOI: 10.1016/j.soilbio.2012.02.006.

Kučera, M. (2016). The Czech Republic. In C. Vidal, I. Alberdi, L. Hernández \& J.J. Redmond (Eds.), National Forest Inventories - Assessment of Wood Availability and Use (pp. 307-325). Springer International Publishing Switzerland. DOI: 10.1007/978-3-319-44015-6.

Lehmann, J. \& Kleber M. (2015). The contentious nature of soil organic matter. Nature, 528, 60-68. DOI: 10.1038/nature16069.

MacLean, D.A. \& Wein R.S. (1978). Litter production and forest floor nutrient dynamics in pine and hardwood stands of New Brunswick, Canada Ecography, 1, 1-15. DOI: 10.1111/j.1600-0587.1978.tb00933.x.

Magri, D., Vendramin, G.G., Comps, B., Dupanloup, I., Geburek, T. Gömöry, D., Latałowa, M., Litt, T., Paule, L., Roure, J.M., Tantau, I., van der Knaap, W.O., Petit, R.J. \& de Beaulieu J.-L. (2006). A new scenario for the quarternary history of European beech populations: palaeobotanical evidence and genetic consequences. New Phytol., 171, 199-221. DOI: 10.1111/j.1469-8137.2006.01740.x.

Michéli, E., Schad, P., Spaargaren, O., Dent, D. \& Nachtergaele F. (2007) World reference base for soil resources 2006. A Framework for international classification, correlation and communication. UISS-ISRIC-FAO, World Soil Resources Reports, 103, 1-128

Mikeska, M., Vacek, S., Prausová, R., Simon, J., Minx, T., Podrázský, V., Malík, V., Kobliha, J., Anděl, P. \& Matějka K. (2008). Lesnicko-typologické vymezení, struktura a management prirozených borů a borových doubrav $v$ ČR. Kostelec nad Černými lesy: Lesnická práce.

Nannipieri, P., Ascher, J., Ceccherini, M.T., Landi, L., Pietramellara, G. \& Renella G. (2003). Microbial diversity and soil functions. Eur. J. Soil Sci., 54, 655-670. DOI: 10.1111/ejss.4_12398.

Neuhäuslová, Z., Blažková, D., Grulich, V., Husová, M., Chytrý, M., Jeník, J., Jirásek, J., Kolbek, J., Kropáč, Z., Ložek, V., Moravec, J., Prach, K., Rybníček, K., Rybníčková, E. \& Sádlo J. (1998). Mapa potencionální přirozené vegetace České republiky. Praha: Academia.

Ostroumov, S.A. (2002). New definitions of the concept and terms ecosystem and biogeocoenosis. Doklady Biological Sciences, 383, 141-143.

Park, S., Kub, Y.K., Seo, M.J., Kim, D.Y., Yeon, J.E., Lee, K.M., Jeong, S.-C., Yoon, W.K., Harn, C.H. \& Kim H.M. (2006). Principal component analysis and diskriminant analysis (PCA-DA) for discriminating profiles of terminal restriction fragment lenght polymorphism (T-RFLP) in soil bacterial communities. Soil Biol. Biochem., 38, 2344-2349. DOI: 10.1016/j.soilbio.2006.02.019.

Pizzeghello, D., Nicolini, G. \& Nardi S. (2001). Hormone-like activity of humic substances in Fagus sylvaticae forests. New Phytol., 151, 647-657. DOI: 10.1046/j.0028-646x.2001.00223.x.

Ponge, J.-F. (2013). Plant-soil feedbacks mediated by humus forms: A review. Soil Biol. Biochem., 57, 1048-1060. DOI: 10.1016/j.soilbio.2012.07.019.

Ponge, J.-F. (2016). The soil under the microscope. The optical examination of a small area of Scots pine litter (Pinus sylvestris L.). Sarrebruck: Éditions Universitaires Européennes.

Priha, O. \& Smolander A. (1999). Nitrogen transformations in soil under Pinus sylvestris, Picea abies and Betula pendula at two forest sites. Soil Biol. Biochem., 31, 965-977. DOI: 10.1016/S0038-0717(99)00006-1.

Priha, O., Hallantine, T. \& Smolander A. (1999). Comparing microbial biomass, denitrification enzyme activity, and numbers of nitrifiers in the rhizospheres of Pinus sylvestris, Picea abies and Betula pendula seedlings by microscale methods. Biol. Fertil. Soils, 30, 14-19. DOI: 10.1007/ s003740050581. 
Rao, M.A., Violante, A. \& Gianfreda L. (2000). Interaction of acid phosphatase with clays, organic molecules and organo-mineral complexes: kinetics and stability. Soil Biol. Biochem., 32, 1007-1014. DOI: 10.1016/ S0038-0717(00)00010-9.

Rejšek, K. (1991). Acid phosphomonoesterase activity of ectomycorrhizal roots in Norway spruce pure stands exposed to pollution. Soil Biol. Biochem., 23, 667-671. DOI: 10.1016/0038-0717(91)90081-T.

Rejšek, K. (2006). The quantitative estimate of bioavailable inorganic phosphorus content in forest soils by the modification of the anion-exchange resin method. Soil and Water Research, 1, 117-126. DOI: 10.17221/6513SWR.

Roscoe, R., Vasconcellos, C.A., Neto, A.E.F., Guedes, G.A.A. \& Fernandes L.A. (2000). Urease activity and its relation to soil organic matter, microbial biomass nitrogen and urea-nitrogen assimilation by maize in a Brazlian oxisol under no-tillage and tillage systems. Biol. Fertil. Soils, 32, 52-59. DOI: $10.1007 / \mathrm{s} 003740000213$.

Samec, P. (2006). Change in acid phosphomonoesterase and urease activities and in microbial biomass after air-drying of top-soil horizons from natural sites of Scots pine (Pinus sylvestris L.): preliminary results. Phytopedon (Bratislava), 5, 28-35.

Samec, P. (2008). Biochemistry of ecological processes in the zonal forest soils. Review. Rep. For. Res., 53, 230-238.

Samec, P., Kučera, A. \& Tuček P. (2014). Fluctuations in the properties of forest soils in the Central European Highlands (Czech Republic). Soil and Water Research, 9, 201-213. DOI: 10.17221/68/2013-SWR.

Sariyildiz, T. (2015). Effects of tree species and topography on fine and small root decomposition rates of three common tree species (Alnus glutinosa Picea orientalis and Pinus sylvestris) in Turkey. For. Ecol. Manag., 335, 71-86. DOI: 10.1016/j.foreco.2014.09.030.

Sewerniak, P. \& Piernik A. (2012). Regression models for impact of soi properties on site index class of Scots pine (Pinus sylvestris L.) stands in south-western Poland. Sylwan, 156, 563-571.

Stevenson, B., Sparling, G.B. \& Schipper L.A. (2004). Pasture and forest soil microbial communities show distinct patterns in their catabolic respiration response at a landscape level. Soil Biol. Biochem., 36, 49-55. DOI: 10.1016/j.soilbio.2003.08.018.
Šindelář, J., Frýdl, J. \& Novotný P. (2007). Towards the Scots pine (Pinus sylvestris $\mathrm{L}$.) regional populations (ecotypes) characteristics in the Czech Republic. Rep. For. Res., 52, 148-159.

Tarafdar, J.C., Yadav, R.S. \& Meera S.C. (2001). Comparative efficiency of acid phosphatase originated from plant and fungal sources. J. Plant Nutr. Soil Sci., 164, 279-282. DOI: 10.1002/1522-2624.

Ulrich, B. (1995). The history and possible cause of forest decline in Central Europe, with particular attention to the German situation. In EC - UN/ ECE, forest soil condition in Europe. Results of a large-scale soil survey. Brussel, Geneva: UN.

Vacek, S., Vacek, Z., Bílek, L., Simon, J., Remeš, J., Hůnová, I., Král, J., Putalová, T. \& Mikeska M. (2016). Structure, regeneration and growth of Scots pine (Pinus sylvestris L.) stands with respect to changing climate and environmental pollution. Silva Fenn., 50, 1564. DOI: 10.14214/sf.1564.

Vacek, S., Vacek, Z., Remeš, J., Bílek, L., Hůnová, I., Bulušek, D., Putalová T., Král, J. \& Simon J. (2017). Sensitivity of unmanaged relict pine forest in the Czech Republic to climate change and air pollution. Trees, 31, 1599-1617. DOI: 10.1007/s00468-017-1572-0.

Vanmechelen, L., Groenemans, R. \& Van Ranst E. (1997). Forest soil condition in Europe. Results of a large-scale soil survey. Brussels, Geneva: EC-UN/ ECE.

Vavř́ček, D. \& Chaloupka V. (2005). Nezbytnost definice půdního prostředí při mapování SLT na př́kladu oblasti Babí lom. In Douda, J., Joza, V. \& Šamonil P. (Eds.), Problematika lesnické typologie VII (p. 24). Praha: ČZU.

Webster, R. (2001). Statistics to support soil research and their presentation. Eur. J. Soil Sci., 52, 331-340. DOI: 10.1046/j.1365-2389.2001.00383.x.

Weintraub, M.N., Scott-Denton, L.E., Schmidt, S.K. \& Monson R.K. (2007) The effects of tree rhizodeposition on soil exoenzyme activity, dissolved organic carbon, and nutrient availability in a subalpine forest ecosystem. Oecologia, 154, 327-338. DOI: 10.1007/s00442-007-0804-1.

Yavitt, J.B., Wright, S.J. \& Wieder K. (2004). Seasonal drought and dry-season irrigation influence leaf-litter nutrients and soil enzymes in a moist, lowland forest in Panama. Austral Ecol., 29, 177-188. DOI: 10.1111/j.1442 9993.2004.tb00309.x. 